\title{
천년개발목표 달성을 위한 한국의 기여
}

송 민 순 / 외교통상부 장관

제프리삭스 교수님,

신장범 $\mathrm{KOICA}$ 총재님,

국내외 $\mathrm{ODA}$ 분야 전문가 여러분,

\section{I . MDGs 달성도 검토 필요성}

저는 오늘 우리 정부가 UN천년개발목표(MDGs) 의 이행을 점검하고 향후 추진계획을 논의하기 위 하여 $\mathrm{ODA}$ 국제컨퍼런스를 주최하게 된 것을 대단 히 기쁘게 생각합니다.

$\mathrm{UN}$ 천년개발목표(MDG)는 최근 국제사회의 주요 화두가 되고 있으며, 이를 달성하기 위한 다양한 대외원조 사업들이 시행되고 있습니다. 이러한 사 업들은 절대빈곤층의 감소, 초등교육의 확산, 5 세 이하 유아 사망률 감소란 측면에서 괄목할 만한 성 과를 내고 있습니다.
그러나 아프리카 전역을 비롯하여 많은 개도국에 확산되고 있는 $\mathrm{AIDS}$ 감염률은 오히려 증가하고 있으며, 서부사하라 이남 지역의 절대빈곤문제 해 결도 별다른 진전을 보고 있지 못한 실정입니다.

따라서 저는 목표달성 연도 2015년에 대해 중간 반환점이 되는 금년이야 말로 천년개발목표의 추 진상황에 대한 면밀한 점검이 필요한 시점이라고 생각합니다.

금번 회의를 통해 국내외 전문가 및 국제개발기구 가 천년개발목표의 이론적 기틀을 제공한 제프리 삭스 교수와 함께 전반적인 천년개발목표 달성정 도를 점검하고, 미진한 목표에 대한 이행을 촉진시 키는 모멘텀을 창출할 수 있기를 기대합니다. 


\section{II. 한국정부의 회의 주최 의의}

또한 금번 회의를 한국 정부가 개최하게 된 것은 몇 가지 측면에서 특별한 의미를 갖고 있다고 생각 합니다.

한국은 1945년 이후 국제원조를 받은 대표적 수원 국 중 하나였습니다. 그러나 한국은 90 년대 초 공 여국으로 전환되었고, 현재 지속적으로 국제사회 에 대한 기여를 높여나가고 있습니다.

한국은 2 차 대전 이후 탄생한 개도국 중에서 경 제· 사회발전을 가장 모범적으로 이루었다는 평가 받고 있습니다.

이러한 한국의 발전이 국제사회의 지원에 힘입은 바 컸음을 감안할 때, 한국의 발전경험이 국제사회 의 천년개발목표 달성 노력에 시사하는 바가 매우 크다고 생각합니다.

노무현 대통령께서는 국제개발원조 문제와 한국의 국제적 기여증진에 각별한 관심을 갖고 있습니다. 지난해 아프리카 개발이니셔티브 발표와 한 - 아프 리카 포럼, 그리고 금번 한국의 컨퍼런스 개최는 노대통령의 의지가 반영된 것입니다.

이러한 한국의 특별한 국제개발원조에 대한 역사 적, 정책적 맥락을 조망하면서, 저는 오늘 이 자리 를 빌려 한국 정부가 발전시켜나가고 있는 국제개
발원조 정책의 기조를 간략히 소개하고자 합니다.

\section{III. 한국정부의 국제개발원조 정책 방향}

한국 정부는 국제사회가 세계 11 위의 경제국가에 게 어떤 기대를 하고 있는지를 잘 알고 있습니다. 이러한 국제사회의 기대에 부응하고, 우리 나라의 지난 어려웠던 시기를 회상하면서, 한국 정부는 국 제개발원조를 양과 질의 두 가지 측면에서 선진국 형으로 전환시켜나가고 있습니다.

첫째, 한국 정부는 지난해 ODA 對 GNI 비율을 2009 년에는 $0.1 \%$ 로 2015 년까지 $0.25 \%$ 로 확대해 나가겠다는 계획을 발표하였습니다. 이러한 목표 를 차질 없이 이행한다면 한국의 국제개발원조 (ODA) 총액은 2009년 약 10억불, 2015년 약 32억 불에 이를 것으로 전망됩니다.

여기에는 한국의 1 인당 GDP가 아직 세계 30 위권 에 머물러 있는 것과 북한을 지원해야 하는 특수한 사정을 가지고 있는 점이 주요 제약요인이 되고 있 습니다.

그러나 한국 정부와 국민은 여러 가지 어려운 상황 하에서도, 한국의 국제개발원조를 확대할 수 있는 여건을 조성하기 위해 지속적인 노력을 경주해 나 갈 것입니다. 
둘째, 한국 정부는 UN, World Bank, OECD 등 국제개발기구와 여타 공여국 및 수원국과 협력하 여 원조전달체제의 효율화, 우리의 개발경험 전수, 수원국의 Good Governance 확립을 위해서도 적 극 기여해 나갈 것입니다.

이를 위해 한국 정부는 2010년을 목표연도로 하여 $\mathrm{OECD}$ 개발원조위원회(DAC)에 가입하기 위한 준 비를 진행하고 있습니다.

셋째, 한국정부는 $40 \%$ 이상을 차지하고 있는 유상 원조 비율을 점차 낮추어 가고 있고, 국제적 수준 의 대외원조평가 시스템을 구축해 나가고 있습니 다. 아울러 무상원조와 유상원조간의 연계를 강화 시켜 나갈 것입니다.

넷째, 한국 정부는 국제개발원조정책의 안정성을 확보하고 효과적인 집행체제를 구축하기 위하여 $\mathrm{ODA}$ 에 대한 법적 기반을 마련할 예정입니다.

이를 위해 한국 정부는 '국제개발협력기본법 제 정'을 검토하고 있으며, 원조집행 중심기관인 한 국국제협력단(KOICA)의 전문성 제고와 집행 능력 강화에도 노력을 경주하고 있습니다.

다섯째, 한국정부는 원조의 효과성 증진을 위하여 국제기구와 수원국을 종합적으로 연계시키는 원조 를 시행하고자 합니다.
일례로, 한국 정부는 지난해 3월 노무현 대통령께 서 아프리카 3 개국 순방시 발표한아프리카 개발 을 위한 이니셔티브」를 이행하기 위해, 한국과 수 원국간 양자 협력과 함께 다자차원에서 UNDP와 2000 만 달러 규모의 공동사업을 시행하는 두 가지 방식을 채택하고 있습니다.

마지막으로, 한국은 천년개발목표 이행 실태와 우 리의 국제개발협력정책간의 연계를 강화함으로써 천년개발목표 달성에 보다 직접적으로 기여하고자 합니다.

이를 위해 항공권에 1달러씩 부과하는 『국제빈곤 퇴치기금제도』도입과 아울러『혁신적 개발재원`을 위한 리딩그룹의 의장국 총회 및 OECD Non$\mathrm{DAC}$ 공여국 회의를 금년 9월 서울에서 개최할 예 정이며, 금년 하반기 중에는 우리 정부의 천년개발 목표보고서를 발간하여 UN 등 국제사회에 제시할 계획입니다.

한국의 대외원조 규모는 아직 선진국 수준에는 못 미치지만, 한국은 국제사회에 대한 기여를 확대해 야 한다는 건설적인 토론이 다양한 시민사회계층 으로부터 가장 활발히 일어나고 있는 국가 중의 하 나라고 생각합니다.

특히 한국은 지난 수십년간 국제사회로부터 개발 원조를 받은 경험과 효율적인 정책추진체제 수립 을 통해 경제발전을 이룩한 역사를 가진 대표적 
인 국가입니다. 우리 정부는 이 귀중한 경험을 개 발경험의 전수라는 방식으로 개도국에 전파하여 천년개발목표 달성에 특색 있게 기여해 나가고자 합니다.

\section{MDGs 이행을 위한 국제적 의지 결집의 필요}

지난 50 년간 국제사회는 약 2.3 조불의 엄청난 금 액의 국제개발원조자금(ODA)을 개도국에 지원하 였습니다. 그러나 아쉽게도 그 효과에 대해서는 국 제사회의 평가가 일치하고 있지는 않고 있습니다.

일각에서는 국제개발원조의 주요 문제점으로 수원 국의 경제적 효율성 부족, 구조적 부패 외에도 가 버넌스 분야의 실패, 즉 정부역량의 미비 등을 지 적하고 있는 것도 사실입니다.

그러나 제프리삭스 교수도 강조한 것처럼, 일반적 인 견해는 '빈곤의 함정' 에 빠져 있는 최빈 개도국 들은 외부의 도움이 없이는 '경제발전의 사다리' 에 첫발을 디디기가 매우 어렵다는 것입니다. 따라 서 천년개발목표를 차질 없이 이행하기 위한 국제 사회의 노력은 계속되어야 할 것입니다.

이를 위해서는 국제개발원조 증액에 대한 각국 지
도자들의 정치적 의지와 국민들의 합의가 그 무엇 보다 중요하다고 생각합니다. 그리고 현재 천년개 발목표 달성에 적극 기여하고 있는 나라들에게 그 에 합당한 찬사가 주어져야 할 것입니다.

동시에, 외국으로부터 제공되는 대외원조가 수원 국내에서 기대한 효과를 나타내도록 하기 위한 수 원국의 노력도 필요하다고 봅니다. 천년개발목표 는 단순히 부국의 빈국에 대한 원조 약속이 아니라 공여국과 수원국이 공동으로 천명한 상호간의 약 속이라는 점을 명심해야 합니다.

오늘 컨퍼런스에서 국민적 희망, 지도자의 열정, 정선된 발전 목표와 실천 계획, 최소한의 재원이 마련된다면 '빈곤의 함정' 을 극복할 수 있다는 사 실을 확인하는 계기가 되기를 바랍니다. 한국의 개 발 경험도 동 논의에 기여하게 되기를 바랍니다.

끝으로 오늘 국제컨퍼런스에 참여해 주신 여러 전 문가 여러분과 행사의 준비와 진행에 애쓰신 직원 여러분께 심심한 격려의 말씀을 드립니다. 아울러, 오늘 컨퍼런스가 국제기구, 수원국, 공여국의 개발 원조 관계자, 학계 및 시민단체 전문가간의 연대를 강화하고 향후 더 많은 발전적 논의를 이끌어 내는 계기가 되기를 기대합니다. 